Original article

\title{
Meaning of parenting as a teenager
}

\author{
Carolina Antolinez Figueroa' \\ Carlos Julio Saavedra Cantor ${ }^{2}$ \\ Ana Helena Puerto Guerrero 3 \\ Carol Margeth Calderón Romero ${ }^{4}$
}

\section{Meaning of parenting as a teenager}

Objective. Describe the meaning of parenting as a teenager. Methods. Study of the qualitative approach with phenomenological approach in the fourth village of San Cristobal (Bogotá, Colombia). The information was obtained by means of semi-structed interviews, participant observation, photos, daily and focal groups field. The information analysis was performed using the phenomenological method of Amadeo Giorgi. Results. The meaning of their parenthood in the adolescents revealed five units of sense: emotional ambivalence, paternity as a process of learning, changes in lifestyle, making a life project and support networks. Conclusion. Teenage fatherhood was interpreted by the participants as a positive change and assumed a patriarchal perspective.

Descriptors: paternity; pregnancy in adolescence; community health nursing; qualitative research (source: MeSH-NCBI).

\section{Significado de ser padre siendo adolescente}

Objetivo. Describir los significados de ser padre desde la visión del adolescente mismo. Métodos. Estudio de enfoque cualitativo con abordaje fenomenológico realizado en la Localidad Cuarta de San Cristóbal (Bogotá, Colombia). La información se obtuvo mediante entrevistas semiestructuradas, observación participante, fotografías, grupos focales y diarios de campo. El análisis de la información se realizó mediante el método fenomenológico de Amadeo Giorgi. Resultados. Los significados de la paternidad en los adolescentes develaron cinco unidades de sentido: ambivalencia emocional, paternidad como proceso de aprendizaje, cambios en estilo de vida, formación de proyecto de vida, y redes de apoyo. Conclusión. La paternidad adolescente fue interpretada por los participantes como un cambio positivo y es asumida desde una visión patriarcal.

1 Nurse, Master Student. Universidad Nacional de Colombia. Bogotá, Colombia. email: cantolinezf@unal.edu.co

2 Nurse, Specialist. Universidad Nacional de Colombia. Bogotá, Colombia. email: cajsaavedraca@unal.edu.co

3 Nurse, Master. Associate Professor, Universidad Nacional de Colombia. Bogotá, Colombia. email: hpuertog@unal. edu.co

4 Nurse, Student of Specialization. Universidad Nacional de Colombia. Bogotá, Colombia. email: cmcalderonr@unal. edu.co

Article linked to research: Meaning of parenting as a teenager in the village 4 of San Cristobal, Bogotá D.C. 2013.

Conflicts of interest: None.

Received: February 21st 2017.

Accepted: August 30th 2017.

How to cite this article: Antolinez C, Saavedra CJ, Puerto AH, Calderón CM. Meaning of parenting as a teenager. Invest. Educ. Enferm. 2017; 35(3): 348-355

DOI: 10.17533/udea.iee.v35n3a11 
Descriptores: paternidad; embarazo en adolescencia; enfermería en salud comunitaria; investigación cualitativa.

\section{Significado de ser pai sendo adolescente}

Objetivo. Descrever os significados de ser padre sendo adolescente. Métodos. Estudo de enfoque qualitativo com abordagem fenomenológico realizado na Localidade Cuarta de San Cristóbal (Bogotá, Colômbia). A informação se obteve mediante entrevistas semiestruturadas, observação participante, fotografias, grupos focais e diários de campo. A análise da informação

\section{Introduction}

According to the World Health Organization, 16 million pregnancies in adolescents are reported each year, with complications during childbirth and pregnancy being the second leading cause of mortality in this age group.(1) in Colombia, $17.4 \%$ of women between the ages of 15 and 19 have already been mothers or are waiting for their first child, and it is important to emphasize that these women predominate in rural areas, few years of schooling and low educational levels. ${ }^{(2)}$ in the City of Bogotá (Colombia) during 2014, 16686 children of women aged 15 to 19 years were born, ${ }^{(3)}$ providing the locality of San Cristóbal almost one in ten of these children. ${ }^{(4)}$

Adolescent paternity brings with it the decrease of the social and economic capital of a country, whereas it provokes in the adolescent men situations like desertion student. ${ }^{(5)}$ Reproduction of the economic poverty, family and social rejection, loss of Employment and educational opportunities, among others. ${ }^{(6)}$ At the same time, paternity is associated with the process of building masculinity, ${ }^{(7)}$ accelerates the transition to adulthood and implies a process of adaptation and learning that generates challenges, aspirations, challenges and social and personal changes, to become Charge of a newborn and a family. ${ }^{(8)}$ In this context, the objectives of sustainable development, propose that for the year 2030, universal access to sexual and reproductive health services is required, including se realizou mediante o método fenomenológico de Amadeo Giorgi. Resultados. Os significados da sua paternidade nos adolescentes revelaram cinco unidades de sentido: ambivalência emocional, paternidade como processo de aprendizagem, mudança no estilo de vida, formação de projeto de vida, e redes de apoio. Conclusão. A paternidade adolescente foi interpretada pelos participantes como uma mudança positiva e é assumida desde uma visão patriarcal.

Descritores: paternidade; gravidez na adolescência; enfermagem em saúde comunitária; pesquisa qualitativa.

family planning, information and education, as well as the need to strengthen Knowledge of sexual and reproductive health to combat adolescent pregnancy and sexually transmitted infections. ${ }^{(9)}$ for its part, during the year 2014 Colombia raised the national policy of sexuality, sexual rights and reproductive rights, in which it is pointed out that adolescent pregnancy perpetuates social inequities and therefore requires national actions and to lessen this phenomenon. ${ }^{(10)}$ In turn, the National Council for Economic and Social policy stresses that the approach of adolescent pregnancy should be carried out from an approach that includes the social determinants of health, to reduce the different social and economic gaps that They cause this phenomenon among teenagers. ${ }^{(11)}$ In addition, in Colombia, studies and policies on the prevention of adolescent pregnancy have focused on women, minimizing the role and responsibility of men, so this research sought to describe the meanings of their paternity in adolescent parents attending the Secretary of Social integration, the Community Development Centre (CDC) La Victoria, of the fourth locality of San Cristóbal de Bogotá.

\section{Methods}

Qualitative type study, descriptive scope and phenomenological approach, in which seven adolescent parents participated between 15 and 19 years. The sampling of the participants was intentional, according to the fulfilment of the criteria of inclusion and to achieve the saturation 
of data, so that a deep and detailed description of the meanings of the adolescent paternity was obtained. The inclusion criteria were: being an adolescent father between 15 and 19 years of age, assisting the CDC with victory and accepting participation in the investigation through informed consent or assent; At the same time. Those who were a teenage father were excluded for the second or more times and those with cognitive disabilities.

The investigative process was carried out between August 2013 and August 2014 at the CDC La Victoria, of the fourth locality of San Cristóbal (Bogotá, Colombia), located in an area of high social vulnerability, which converges different problems Social such as "Pandillismo", the use of psychoactive substances, adolescent pregnancy, and domestic violence, among others. ${ }^{(12)}$ Likewise, the participating adolescent parents received support from the CDC of the Food Safety program for adolescent mothers, which consisted of the delivery of a $\$ 40$ food voucher, aid that was conditioned to the Assistance for parenting and maternity training for adolescent mothers and fathers. The gathering of the information was carried out through two interviews-first a semi-structured one and then a second one to deepen some essential topics-, participant observation, photographs, focal groups and field diaries. The approximate duration of the interviews was 30 minutes. The participant observation was carried out in other spaces different to the CDC of the victory as sports and cultural meetings organized by the researchers to generate a greater approach with the participants, among which the realization of $A$ championship of Micro football, and attendance to museums by suggestion of the adolescent parents, to deepen in the description of the meanings of the adolescent paternity. The two focal groups involved the seven adolescent parents, helped with the saturation of data and with the understanding depth of the meanings of paternity for the teenager. The type of record was of narrative and audio-visual type, and the triangulation processes of the information obtained were developed, to increase the validity and quality of the research.

The information was codified in the Atlas software. TI 7 and the analysis was carried out through the phenomenological method of Amadeo Giorgi, which led to a description of paternity through the categorization of all the findings in units of meaning, based on the Philosophy of Edmund Husserl and Merleau-Ponty. ${ }^{(13)}$ Otherwise, to maintain the purposes, objectives and requirements of the qualitative methodological approach, the criteria of auditability, credibility, transferability and dependence were considered. With regard to ethical considerations, the investigation complied fully with the provisions of resolution 8430 of the Ministry of Health and Social protection of Colombia, therefore the investigation was classified in the category without risk. ${ }^{(14)}$ (It is important to emphasize that the present study was financed by the Research and Extension Directorate of the National University of Colombia- Sede Bogotá, within the framework of the National Program of research, creation and innovation Seders of the Universidad Nacional de Colombia 2013-2015.

\section{Results}

It was found that, of the seven adolescent parents participating in the investigation, three were 17 years old; two, 18 years, and two, 19 years old. According to the educational level, five had incomplete baccalaureate; One, full baccalaureate, and one was a complete technician. As for who or who they lived with, three coexist with their families of origin, two live alone and two with their partners. The neighbourhoods inhabited by the seven adolescents belong to the socioeconomic stratum 2 ( 1 is the lowest and 6 is higher). The seven adolescent parents received financial aid from the state, which consisted of a food bond, provided they attended the maternity and paternity preparation courses offered by the CDC victory, and only four received help Economic of their families. The cross analysis of the diverse sources of data used in the study allowed to identify the following units of meaning of the meanings of their paternity for these adolescent parents: emotional ambivalence, paternity as a process of Learning, lifestyle changes, life project formation and support networks. We then describe the units of sense found, with their respective essential themes. 


\section{Emotional ambivalence: Between happiness and fear}

Paternity generates in adolescent men ambivalent emotions, as happiness and fear at the same time; happiness, by the possibility of joining even more with their partners, and fear, so that their families would think.: For at first, I gave as emotion of joy that I was going to be a father for the fruit of my love with her, but also gave me as fear of what I would say her mom and my parents (P3). Also, parenting in adolescents causes fear due to the acquisition of the economic, family and emotional responsibilities that this role carries, as well as conveying the news to the families: that suddenly one day I will lose them, to separate me from them, not because I want, but because they make us separate, or lose them both already definitively because you may not have how to respond (P3). Likewise, happiness, fear, anxiety and anguish are shown: for at the same time both joy and emptiness, because I did not know what to do, what I was going to say to my family before this, if you understand me, because I just heard I felt like tickle, as something I can't even explain, and as an anxiety to know you already, but then think of everything that's coming (P5).

\section{Paternity as a learning process}

In this sense unit, several essential topics were identified. The first important and characteristic topic of the learning process that involves fatherhood is learning to provide and feel love: I have learned that the child moves with whom he feels most safe, with whom he better stimulates it, because until the sun today the child has moved CU Ando I touched his belly and I have learned to give affection that way to him (P4); That I could learn things that I did not know, that I can give affection to a person without seeing it; I have never been affectionate because my father raised me like this and I have always spent it alone since childhood, but now I have learned to love it, to give it affection, especially to pamper it, more than everything being in the belly (P6).

The second topic is the fear of repeating stories, for which the adolescent parents mentioned that they have lived positive experiences and good examples of their parents or other people who took the role of parents for them, in order to be good examples for their Children: From my dad I would not take any example, because he what he did was just to leave us thrown out for being in love with another woman, what I would do is the opposite and take good examples to be a good dad (P7); My dad has always fought, he has never starved to death or anything, and he has responded for us. That's why I think I do that, because he every Sunday he took us out and that was a good example of my dad (P5).

Paternity as a learning process also represents for adolescent parents a motive for struggle, which consists in the acquisition of responsibilities, summarized mainly in the economic responsibility to provide sustenance for their new Family; So, paternity is the main reason to include teen parents in the work world. Likewise, these responsibilities are acquired by the adolescent parents to show their families, their partners and their future children, the achievements that can achieve their dedication and motivation to bring forth their family: Well now I must finish the most Soon to study, because one without a studio is no longer anyone, anywhere you go to ask for work, ask for a high school carton, whether to sweep the streets (P3); A child is not to tie it to one, but it always has one to take more responsibility than it has being lower (P4); It's just as cool to know that you have someone else to live for, and that's like having another happiness (P2). In addition, adolescents point out that a parent is the one who establishes the rules, the authority, and who cares and provides his family with what is necessary, as evidenced in the following phrases: Being a parent is giving the permits, tidying the house, giving him what he needs, say, give him what he needs in the material, economically, that's what l've tried most, not much affectively (P2); On the one hand being a father is to give love to the children and the woman of one, but in my case as I am unaffectionate and generally one as a man as that does not flow to one like them, then my responsibility is in the financial support to my children and To my wife, who are missing nothing, and because now she has to stay looking after the baby (P3). 


\section{Changes in lifestyles}

Identified changes in lifestyles, such as ending friendships that boost the use of psychoactive substances and abandoning tendencies to unprotected sexual intercourse and attending youth parties constantly. In the face of bad friendships, the participants referred that their children became a struggle to get ahead and be better people: I was a barrista (a type of gang belonged to a football team), and if, say, if I had remained a "barrista", I could not ofering my son nothing, I would only concentrate on wandering, drinking and being a drunkard, and in itself, the worst (P1). The acquisition of responsibilities curtails the freedom of adolescents to have prior to their new role as parents, since freedom for them is summed to go out to juvenile parties with their peers, consume psychoactive substances and find couples to have sex; Although adolescents recognize as positive these changes that have generated paternity, at the same time they manifest miss those activities with their peers, as mentioned in the following excerpt: It is no longer the same as before, you can no longer farrier (go to Parties) so much, neither smoke (to consume marijuana) so much (P5).

\section{Making of a life project}

The fatherhood conducive that the adolescents project, formulate and, in the best option, carry out their life project, which is summarized in the shaping of a new family and in coexistence with their partner: with the news that she gave to me, I immediately began to think about what would be our lives, and we set out to formulate the plan of life that always make us do, but for several reasons is not achieved. Now there is a motive of strength (the baby) that now forces us to do it to pull it forward (P2).

In the same way, parents create the ideal of forming a family to provide stability for their children in the bosom of a home: And now that I am a father I imagine myself in a home, in a house where my child can grow up, he can have his mom and dad together (P1). However, and despite this ideal, there are obstacles imposed by their in-laws, because the adolescent parents do not have an economic stability to meet the needs of their home, which is why many of them prefer to live with their families of origin and to visit his partner and son in the House of his in-laws: with my mother-in-law very little we have taken and now that he learned that I was pregnant I caught more rage than I had; I have tried to talk to her, but as she does not get anything in her head, because she says no, no and no, she does not want to see me with the daughter, that I am a bad example for her and the baby (P3).

On the other hand, other adolescent parents, despite not having economic stability, visualized from the beginning the coexistence as a couple, as evidenced in the following sentence: As soon as I learned that she was pregnant I knew we should go to live both and I continue working as I was doing, because that will unite us as a new family we are (P2).

\section{Support Networks}

Support networks, such as the family, especially the mothers of adolescent men, guided the care that they had to have with the babies, with their partner and the responsibility that brought with them paternity: She says to me (my mom) how it is That one has to do things with the baby, how one has to treat the baby being in the belly, so one does not see it has to show the affection that feels for that person and so when the child is born, can be born well (P1), my dad didn't like the news very much, he just scolded me and told me why he had gotten his paws so early; While my mom and sister are the ones who have been with me and have helped me with that learning and with the care (P5).

\section{Discussion}

In this study it was identified that adolescent parents have difficulty expressing their feelings to their children and that they assume their role from a patriarchal vision, while being a parent denotes providing economic stability to their new Family and be the person who gives authority at 
home, which is consistent with a study conducted in Uruguay, which shows that adolescent parents have conflicts to demonstrate their feelings by having strong patriarchal traits and assume their role from a Commercial vision for the pressure their families exert. ${ }^{(15)}$ Likewise, as opposed to the patriarchal figure, it is evident that the males appropriate the workforce and therefore of the economic responsibility, which allows them to have the authority on the family bosom, as well as of the dominion of their children and of "their woman" terms and socially they have been categorized as terms of dominance and inequality by several feminist authors. ${ }^{(16)}$

Likewise, it was observed that adolescent paternity fosters that adolescents develop a life project around parenthood, which is concretized in the shaping of a new family, coexistence with their partner and the acquisition of economic responsibilities; So, the adolescent paternity was assumed as a positive change, because they left aside risky behaviours like consuming psychoactive substances, going out with their friends to parties and having unprotected sex. This coincides with a study developed in Brazil that shows that paternity for adolescent men was assumed as a positive factor, because it generated a project of life and the interest to get a job and resume its studies; ${ }^{(17)}$ added to that It is essential for adolescent parents to provide financially for their families. ${ }^{(18)}$ Other studies show that adolescent paternity contributed to the consolidation of masculinity in adolescent men by assuming the role of guardian's economic providers of the new family; Therefore, it was a positive experience that allowed them to stop being teenagers and become men; ${ }^{(19-21)}$ however, in another research, for some adolescent men the experience of adolescent paternity was negative, if That was associated with personal, economic and family problems. ${ }^{(22)}$

The present research found that most of the adolescent parents had not completed their high school studies, were of low socioeconomic strata, received financial aid from the state and some had support from their families. About the foregoing, several investigations reiterate the importance of understanding the economic, political, social and cultural context of adolescents, as the experience of adolescent fatherhood is directly influenced by their Context and the family support with which the adolescent men count. ${ }^{23,24)}$ While it is true that the present study identified positive changes in the lifestyles of adolescent parents, paternity is more easily presented in spaces with lack of job and educational opportunities. In addition, the State and the society do not offer to the adolescent man conditions that favour the exercise of paternity, since in the formulation of the public policies of adolescent pregnancy do not include the expectations and educational needs of the Adolescents and it has been conceived that the problem of adolescent pregnancy is a matter only of women. ${ }^{25,26)}$

In this regard, it is necessary to build public policies capable of recognizing the adolescent man in the exercise of paternity, and formulating them based on the experiences and meanings of the adolescents themselves, considering that the Most teenage parents try to fulfil their responsibilities and few are prepared to raise their children. ${ }^{(26)}$ Adolescent Parenthood is a subject of social, governmental and public health interest, due to its impact on the adolescent Life Project and its association with other problems, such as low levels of schooling and unemployment, which does not allow to close the social gaps and, on the contrary, perpetuates inequity. ${ }^{(21,24)}$ There is, however, a social potential in adolescent parents that must be evidenced through research, and the knowledge acquired in government decisionmaking should be harnessed, bringing young people closer to the spaces of Participation and social construction.

The conclusion of this study is that the adolescent parents conceived their paternity as a positive change, because they formulated a life project, they moved away from their peers and acquired economic and social responsibilities; Becoming a teenager was an exit to stop consuming psychoactive substances and to stop performing other types of juvenile risky behaviours. Concluding, as public policies for the prevention of adolescent pregnancy have traditionally focused 
on women, it is essential that the needs and expectations of adolescent men be considered, developing programs Education that are in line with their sociocultural context. The limitations of this study mainly must do with the adolescent parents selected for this study attending the CDC the victory; However, its location and participation involved a process that overstep The Times initially planned, because the participants expected economic remuneration and some did not want to participate in the study, although they were socialized the importance of research and the confidentiality of information. The development of interviews and focal groups was a wasteful process, since the adolescent parents initially felt uncomfortable to be recorded, so it was necessary to develop interviews of deepening and to carry out activities of Sports and cultural awareness, to deepen the description of the meanings of adolescent paternity.

\section{References}

1. World Health Organization. Adolescent pregnancy [Internet]. 2014[cited 2017 Feb 18]. Geneva: WHO. Available from: http://www.who.int/ mediacentre/factsheets/fs364/en/

2. Ministerio de Salud y la Protección Social de Colombia, Profamilia. Encuesta Nacional de Demografía y Salud 2015 [Internet]. 2016 [cited 2017 Feb 18]. Bogotá: El Ministerio. Available from: http://profamilia.org.co/docs/Libro\%20 RESUMEN\%20EJECUTIVO.pdf

3. Secretaría Distrital de Salud de Bogotá D.C. Diagnóstico Sectorial de Salud [Internet]. 2016 [cited 2017 Feb 18]. Bogotá: Secretaría Distrital de Salud de Bogotá. Available from: http://www.saludcapital. gov.co/Empalme $\% 20$ del\%2 OSector $\% 20$ Salud\%2020122016/DIRECTIVA\%2009\%20 DE\%202015/1\%20\%20DIAGNOSTIC0\%20 SECTORIAL\%20DE\%20SALUD.pdf

4. Secretaría Distrital de la Mujer. Embarazo Adolescente [Internet]. 2016 [cited 2017 Feb 17]. Bogotá: Secretaría Distrital de la Mujer. Available from: file:///C:/Users/HP/Downloads/ InfoMujeres\%20Embarazo\%20Adolescente\%20 2016\%200MEG.pdf

5. Rodríguez E. La paternidad en el adolescente: Un problema social. Arch. Venez. Puer Ped. 2009: 72(3):86-91.
6. Martino MS. Padres adolescentes y jóvenes: debates y tensiones. Rev. Katálysis. 2016; 19(1):91-9.

7. De Jesús-Reyes D, Cabello-Garza ML. Paternidad adolescente y transición a la adultez: una mirada cualitativa en un contexto de marginación social. Iberóforum. 2011; 6(11): 1-27.

8. Molina R. El padre adolescente, su relación parental y de pareja. Última Década. 2011: 19(35):89-110.

9. Organización de las Naciones Unidas. Objetivos de Desarrollo Sostenible [Internet]. Ginebra: UN; 2015 [Cited 2017 Feb 20]. Available from: http:// www.un.org/sustainabledevelopment/es/health/

10. Ministerio de Salud y Protección Social de Colombia. Política Nacional de Sexualidad, Derechos Sexuales y Derechos Reproductivos [Internet]. Bogotá: El Ministerio; 2014 [cited 2017 Feb 20]. Available from: https://www.minsalud.gov.co/sites/ rid/Lists/BibliotecaDigital/RIDE/DE/LIBRO \%20 POLITICA\%20SEXUAL\%20SEPT\%2010.pdf

11. Departamento Nacional de Planeación de Colombia. Documento Conpes 147 "Lineamientos para el Desarrollo de una Estrategia para la Prevención del Embarazo en la Adolescencia y la Promoción de Proyectos de Vida para los Niños, Niñas, Adolescentes y Jóvenes en Edades entre 6 y 19 Años [internet]. 2012. Colombia: [cited 20 Feb 2017]. Available from: https://colaboracion.dnp. gov.co/CDT/Conpes/Social/147.pdf

12. E.S.E. Hospital San Cristóbal. Diagnóstico con Participación Social 2012, Localidad Cuarta de San Cristóbal [Internet]. Bogotá; 2013 [cited 2017 Feb 20]. Available from: http://esesancristobal.gov.

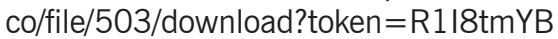

13. Giorgi A. The Descriptive Phenomenological Psychological Method. J. Phenomenological Psychol. 2010; 43(1):3-12.

14. Ministerio de Salud y la Protección Social de la República de Colombia. Resolución 8430 de 1993 "Por la cual se establecen las normas científicas, técnicas y administrativas para la investigación en salud" [Internet]. Bogotá: El Ministerio. 1993 [cited 2017 Feb 20]. Available from: https:// www.minsalud.gov.co/Normatividad_Nuevo/ RESOLUCION\%208430\%20DE\%201993.pdf

15. Bermúdez MS. Padres adolescentes y jóvenes: debates y tensiones. Rev. Katálysis. 2016; 19(1):91-9.

16. González A. Los conceptos de patriarcado y androcentrimo en el estudio sociológico y antropológico de las sociedades de mayoría musulmana. Rev. Papers. 2013; 98(3):489-504.

17. Alvez GP, Patias ND, Garcia AC. Paternidade Adolescente: Um Estudo sobre Autopercepções do Fenômeno. Psicol. Pesqui. 2013; 7(2):230-41. 
18. Costa MM, Frare JC, Nobre J Tavares KO. Maternity and Paternity: The View of The Teenage Couple. Brazilian J. in Health Promot. 2014; 27(1):101-8.

19. Sampaio KJ, Villela WV, Oliveira EM. Meanings attributed to fatherhood by adolescents. Acta Paul. Enferm. 2014; 27(1):1-5.

20. Santos PFBB, Santos ADB, Mota GM, Galhardo TF, Medeiros EB. Significados Da Maternidade/ Paternidade Para Adolescentes que Vivenciam esse Processo. Rev. Enferm. Cent.-Oeste Min. 2015; 5(2):1629-42.

21. Jager ME, Dias AC. A Paternidade na Percepção de Adolescentes de Classes Populares. Psicol. Cienc. Prof. 2015; 35(3):694-710.

22. Venturini APC, Piccinini CA. Percepção de adolescentes não-pais sobre projetos de vida e sobre a paternidade adolescente. Psicol. Soc. 2014; 26:172-82.
23. Patias ND, Fiorin PC, Lima LS, Dias AC. O fenômeno da parentalidade durante a adolescência: reflexões sobre relações de gênero. Rev. SPAGESP. 2014; 15(2):45-62.

24. Costa MMA, Frare JC, Nobre JRS, Tavares KO. A Maternidade e a Paternidade: o Olhar do Casal Adolescente. Rev. Bras. Promoç. Saúde. 2014; 27(1):101-8.

25. Barreto J. La relevancia del conocimiento de las representaciones sociales de los adolescentes varones acerca de la paternidad en la adolescencia para el desarrollo de políticas públicas. Subj. Procesos Cog. 2013; 17(2):17-36.

26. Kiselica M, Kiselica A. The Complicated Worlds of Adolescent Fathers: Implications for Clinical Practice, Public Policy, and Research. Psychol. Men Masc. 2014; 15(3):260-74. 